\title{
Attitude and Actual Behaviour towards Water-Related Green Infrastructures and Sustainable Drainage Systems in Four North-Western Mediterranean Regions of Italy and France
}

\author{
Simone Maria Piacentini ${ }^{1}$ and Rudy Rossetto ${ }^{1,2, *}$ \\ 1 Institute of Life Sciences, Scuola Superiore Sant'Anna, Piazza Martiri della Libertà 33, 56127 Pisa, Italy \\ 2 Center for Climate Change studies and Sustainable Actions, 56127 Pisa, Italy \\ * Correspondence: rudy.rossetto@santannapisa.it
}

Received: 3 April 2020; Accepted: 18 May 2020; Published: 21 May 2020

check for updates

\begin{abstract}
Water-related green infrastructures (WrGIs), also known as blue infrastructures, and sustainable drainage systems (SuDSs) offer services such as stormwater runoff management, water purification, water storage at the intersection of the built environment, and natural systems by mimicking natural hydrological processes. While several papers document the reliability of such infrastructures in providing a variety of water-related services, few studies investigated the actual behaviour and the attitude of different stakeholders to understand the limitations and barriers in WrGIs/SuDSs implementation. In this paper, we investigated these issues by posing a set of questions to 71 qualified stakeholders in three Italian regions (Toscana, Liguria, and Sardegna) and one French region (Provence-Alpes-Côte d'Azur) in the northwestern Mediterranean. The results of the investigation largely show a lack of knowledge on these innovative solutions, although there is a general interest in their implementation both in the Italian and French regions. Barriers are also constituted by the scarcity of the demonstrators implemented, little knowledge on construction and maintenance costs, the absence of a proper regulatory framework, and of fiscal and financial incentives to support private citizens and companies. We finally suggest tools and soft measures that, in our opinion, may contribute to supporting the implementation of WrGIs/SuDSs, especially in view of adapting Mediterranean territories to the challenges posed by climate change. The results of our analyses may be reasonably up-scaled to the whole Mediterranean coastal region.
\end{abstract}

Keywords: nature-based solutions; water-related ecosystem services; stormwater runoff management; climate change; adaptation

\section{Introduction}

Water-related green infrastructures (WrGIs), also known as blue infrastructures, and sustainable drainage systems (SuDSs) offer services such as stormwater runoff management, water purification, water storage at the intersection of the built environment and natural systems by mimicking natural hydrological processes. Some examples of such systems are: rainwater harvesting systems $[1,2]$ including managed aquifer recharge schemes [3], green roofs [4,5], permeable pavements [6], filter drains [7], filter strips [8], vegetated swales [9], constructed wetlands [10,11], and bioretention systems [12]. Several papers document the design, operation, and the reliability of such infrastructures in managing stormwater runoff and providing other water-related services, see [13-21]. WrGIs/SuDSs may also be relevant solutions for tackling climate change impacts by favouring infiltration, reducing runoff volumes, and providing reliable and efficient adaptation measures [22-24]. Because of this, recommendations and policies are supporting their application, for example in the European 
Union [25-27], in Australia with water sensitive cities [28], and in China with the national policy initiative called Sponge City development [29].

However, few studies have been investigating the actual behaviour and the attitude of different stakeholders to understand the limitations and barriers to WrGI/SuDS implementation. A large part of these studies generally refer to green infrastructures (GIs) as a whole (which include WrGIs/SuDSs), intended as (semi-)natural multifunctional (in relation to the ecosystem services they may provide) infrastructures, and strategically developed in networks [30]. Among these, Barnhill and Smardon (2012) [31] explored local stakeholders' perceptions on GIs and ecosystems services from both positive and detracting perspectives in Syracuse, New York (US). They found the respondents displayed confusion about what ecosystems services are, as well as what a GI is. Other studies investigated residents' perceptions on GIs/SuDSs. Everett et al. (2015) [32] examined public perceptions of, and behaviour around, bioswales by interviewing the residents of Portland, Oregon (US) living near bioswales. The authors did find common issues affecting the residents' appreciation and acceptance of bioswales, environmental attitudes, in particular related to awareness and understanding of purpose and function, plant choice and maintenance, and mess and littering. Tsantopoulos et al. (2018) [33] investigated the attitudes toward GIs of eight hundred apartment owners in Athens (Greece) by submitting a structured questionnaire. While they found a positive attitude towards the installation of, e.g., a green roof, trellis, or vertical garden, the respondents were not familiar with the energy savings that may occur from the installation of such infrastructures.In fact, the respondents declared a subsidy from the state was required in order to implement green building solutions. The authors concluded that the participants in their study were not environmentally aware, being mostly interested in the aesthetics of their building. Sañudo-Fontaneda and Robina-Ramírez (2019) [34] ran a survey in three neighbouring communities in Cáceres (Extremadura, Spain), in order to check the potential of SuDSs to be considered for full implementation in southern Europe, by submitting a questionnaire to 276 dwellers. The participants showed significant sensitivity towards the implementation of SUDSs. In Italy, Sturiale and Scuderi (2019) [35] analysed the importance for urban governance to assess the citizens' perception of investments in GIs, and to estimate the benefits of related ecosystem services, as an initial attempt to assess the interactions between stakeholders involved in urban projects for climate change adaptation actions in cities. Recently, Venkataramanan et al. (2020) [36] published a multidisciplinary systematic literature review to synthesise the research on people's existing knowledge about flood risk and GIs, and how that shapes their attitudes and motivation to adopt these new solutions. The authors considered 85 studies, out of 21,000, on GIs for flood management. Twenty studies reported low rates of adoption. The authors finally recommend that researchers should capture data on the human dimensions of GIs such as knowledge, attitudes, intentions, and behaviour across diverse settings more systematically to improve program design and uptake. Zuniga-Teran et al. (2020) [37] interrogated five key challenges for the effective implementation of GIs: (1) design standards; (2) regulatory pathways; (3) socio-economic considerations; (4) financeability; and (5) innovation. The methods included a literature review, case studies, and interviews with resilience managers. The authors highlighted two underlying currents that run across all of the challenges: first, the role of political will as a pre-condition for tackling all challenges holistically; and second, the role of stakeholder engagement in achieving public support, harnessing funding, and maintaining and monitoring GIs in the long term.

Starting from such a background, in this contribution we present the results of a survey run by means of interviews and questionnaires in the Mediterranean areas of Italy (three regions) and France (one region) in order to synthesise evidence on the actual behaviour of local authorities towards the uptake of WrGIs/SuDSs and the attitude of relevant stakeholders, involved in their design, maintenance, or uptake, towards their implementation. The area under analysis is in the northwestern Mediterranean and precisely the four regions of Sardegna, Toscana, Liguria (Italy), and Provence-Alpes-Côte d'Azur (PACA, France; Figure 1). The interviews were run in these neighbouring regions, as this research is part of the activities of the TRIG-Eau INTERREG MARITTIMO project. 


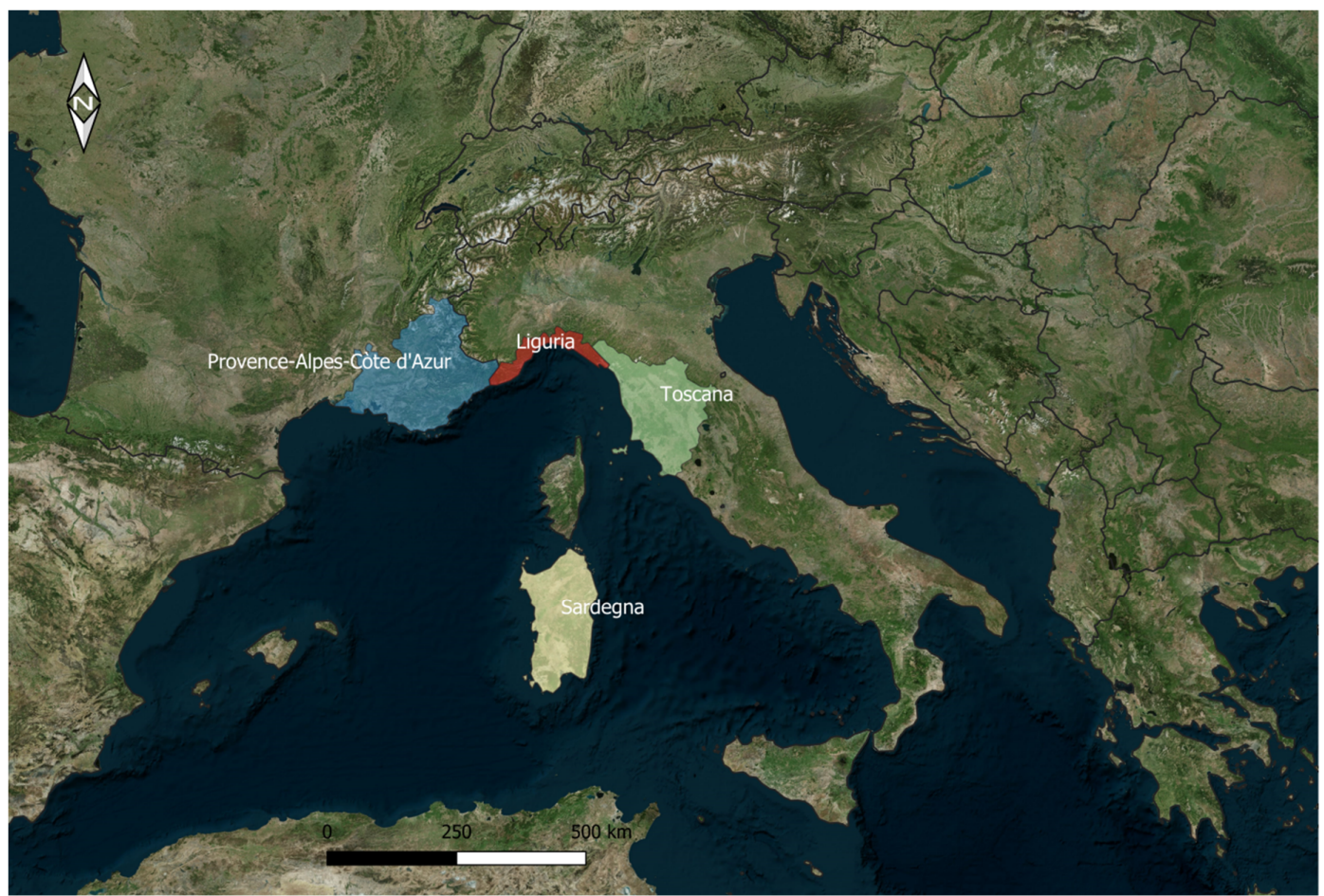

Figure 1. Geographical location of the investigated regions.

Sturiale and Scuderi (2019) [35] affirm that "in Italy, the GIs are still few, limited to individual local initiatives and in any case, are not included in system logic, which is essential for achieving the objectives". While performing a brief search in SCOPUS, using general keywords such as "green infrastructure" or "sustainable drainage system", and "Italy" or "Tuscany" or "Liguria" or "Sardinia", we identified few studies demonstrating local applications [38-40]. Some more information, gathered from grey literature, may be found in [41]. Gimenez-Maranges et al. (2020) [42] recently published a paper where they identified existing pilots, in southern France and in Italy, analysed the transition to adaptive storm-water management and discussed experiences on SuDSs. They conclude that "SuDS are fostered in both countries but while a recent increase in their adoption can be observed in Southern France, their implementation is more limited in Italy".

Our research aims, behind framing the present conditions in the aforementioned areas, at highlighting the perception of relevant technical stakeholders of WrGIs/SuDSs, and identifying barriers and limitations preventing their uptake, while providing information-driven suggestions for supporting the development of green and sustainable engineering design and their diffusion in the four regions.

\section{Materials and Methods}

In order to prepare the present analyses, four major steps were undertaken. Within a broader questionnaire, a set of 23 questions on knowledge, actual behaviour, and attitude towards GIs/SuDSs was prepared, and then delivered to relevant stakeholders in the four areas. The gathered data were validated and then analysed.

As we foresaw potentially limited awareness on the topic of GIs/SuDSs, in order to facilitate the completion of the questionnaire, a brief presentation on stormwater runoff management, and on GIs/SuDSs, was prepared. The two-page presentation also briefly discussed the strategic differences in the management of stormwater runoff between traditional drainage systems and GIs/SuDSs. To facilitate the stakeholders' understanding, the questionnaire also included an appendix in which some of the most relevant types of GIs/SuDSs were presented through illustrative schemes (images modified from SFPUC, 2010 [43]). Particular attention was paid to the questionnaire preparation, in order to allow both direct or remotely run interviews, and even autonomous completion without 
interview. Stakeholders were asked to get familiar with the introduction and the appendix before the interview took place or the questionnaire was completed.

In each of the four regions, we identified, thanks to the support of colleagues taking part in the INTERREG TRIG-Eau project [41], the list of the stakeholders to be interviewed. Such a list was defined during meetings with project partners and was based on the different socio-economic conditions of the areas involved. The following stakeholders (public and private) involved in stormwater runoff management in urban and peri-urban areas were identified: local authorities, regional or national authorities, river basin authorities, land reclamation entities, water utilities, consultant companies or chartered professional organisations and research institutions, construction companies, social housing companies, and citizens' societies (i.e., environmental and/or civil protection societies). At all of the public authorities and research and consultant companies, we interviewed technical staff in charge of activities related to stormwater runoff management. However, at a very small number of stakeholders, this was not possible. The analysis was run from June 2017 to January 2018. Although private citizens play a relevant role in the transition to adaptive stormwater management, we did not interviewed private citizens, as we were interested in understanding the level of knowledge of the technical staff on thebehaviour and attitude.

The title of the questionnaire was: "Investigation on flood risk management in urban and peri-urban areas and on the attitude towards innovative mitigation strategies". The questionnaire queries included binary type (yes, no), ordered (mostly on a Likert scale from 1 to 5 ), and nominal (free response) variables (see e.g., [44-48]).

In the first and second section of the questionnaire, we aimed at gathering basic information for characterising the stakeholders. We asked the interviewed person (or the one compiling the questionnaire) to answer questions about the institution/organisation, type of institution/organisation, and his/her role in the institution. We also required qualitative information on the main features of the area (such as urban, peri-urban or rural; inland or coastal; population size, etc.) in which the institution/organisation was running its main activities. We grouped the questions posed to the stakeholders according to: (i) actual behaviour on WrGI/SuDS implementation (15 questions), (ii) attitude towards WrGIs/SuDSs (eight questions). We formulated questions to assess the actual behaviour, documenting the types of WrGIs/SuDSs that were implemented, as well as the reasons or motivations for using them. We then investigated the attitude of all of the stakeholders towards innovative approaches to urban drainage management, including the use for which they believe WrGIs/SuDSs are more functional, and which actions should/could be set in practice to facilitate their diffusion.

At the end of the survey, we received answers from 79 stakeholders. They were validated and then digitised to be analysed. After the validation process, we had 14 completed sets of answers coming from Liguria, 13 from Sardinia, 22 from Tuscany, and 22 from PACA, for a total of 71 validated questionnaires (Table 1).

Table 1. Number of questionnaires completed and validated per region.

\begin{tabular}{cccccc}
\hline Regions & Liguria & Sardegna & Toscana & PACA & Total \\
\hline N. completed questionnaires & 14 & 13 & 22 & 22 & 71 \\
\hline
\end{tabular}

The answers in ordered variables were analysed both by considering (i) the complete statistical population, (ii) a subset of it constituted only by local authorities, and (iii) a comparison between the data of two groups of interviewees (planners and prescribers). Given the use of ordinate values, often resulting in a non-normal distribution, we performed a non-parametric test to verify and quantify the probability whether the medians belonged to different populations or not. The implemented non-parametric test was the Mann-Whitney U test. Statistical analysis was carried out with Max Stat Lite software (http://www.maxstat.de/; MaxStat Software, 26441 Jever-OT Cleverns, Germany) using a descriptive statistical approach. 


\section{Results and Discussion}

\subsection{Stakeholder Characterisation}

We introduce first a presentation of the interviewed sample characteristics. Out of the 71 questionnaires, the two most represented typologies of interviewed stakeholders (SHs) were local authorities (26 SHs, 15 out of 26 from Italy and 11 from France), and consultants (17 SHs, mostly from Italy, as in the number of 15; Figure 2). The most common role of the interviewed SHs was the decisional one (34 SHs), while 22 SHs indicated technical consultant/scientific advisory functions. Authorities, having chosen the decisional function as the main one, accompanied it with the control and financial functions in many cases. This led us to define two major groups of stakeholders: the planners, the stakeholders linked to public administration with decisional, financial, and control powers, and the prescribers, practitioners/academics/organisations able to influence the planners with their technical/scientific knowledge.

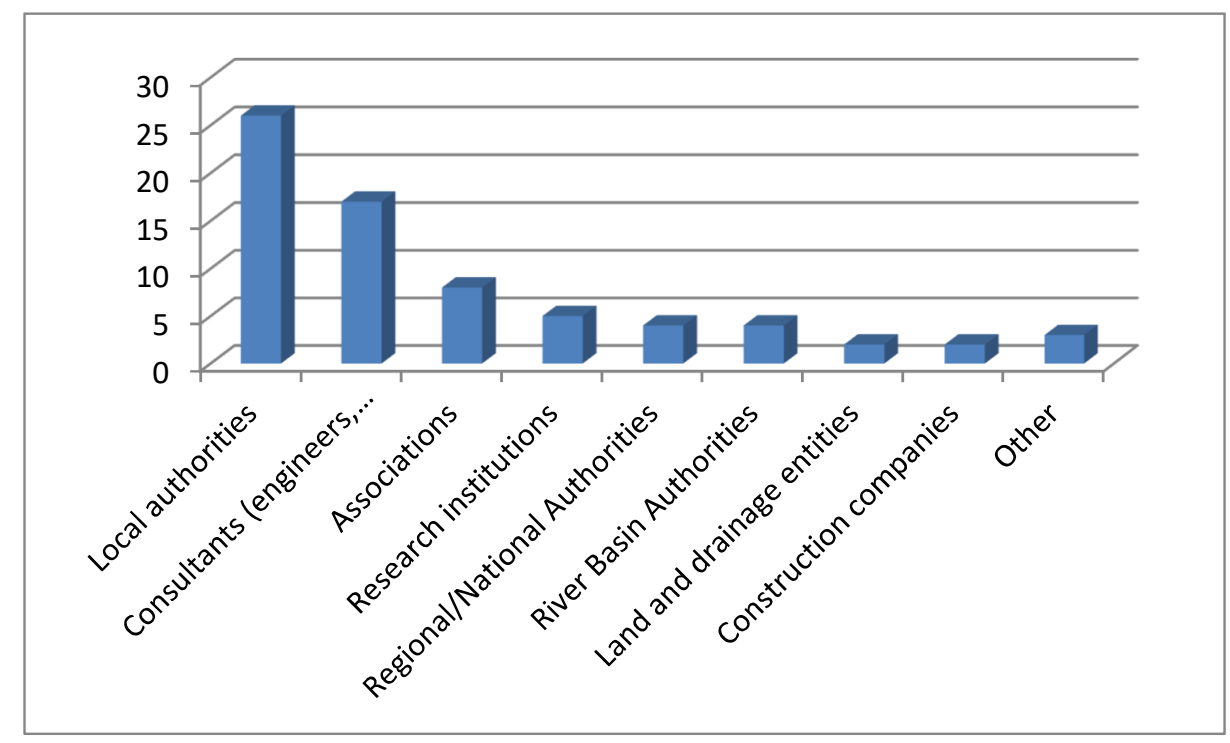

Figure 2. Number of completed questionnaires received per type of stakeholder.

The majority of the stakeholders operate in areas that cover urban, peri-urban and rural areas (37 SHs). In total, the urban area is of interest for 57 out of 71 respondents. The peri-urban area is of exclusive interest for six respondents, while the rural area for five only. The majority of the stakeholders interviewed (41 SHs) acts in areas with more than 50,000 inhabitants. A population above 50,000 inhabitants is indicated with particular frequency by the interviewees from the PACA region (France, $20 \mathrm{SHs}$ out of 22). Eleven SHs act in areas with populations between 50,000 and 25,000 and three in areas with a population between 25,000 and 10,000. The smaller population centres are represented by eight SHs, acting in areas with populations between 10,000 and 5000 inhabitants, seven in areas with populations between 5000 and 1000 inhabitants, and there is only one case of a municipality with fewer than 1000 inhabitants (Figure 3).

Only 38 out of 71 interviewees were familiar with the concept of WrGIs/SuDSs, and only 13 (out of 26) local authorities (five out of 15 from Italy and eight out of 11 from France). Among the consultants and research institutions, 12 out of $17 \mathrm{SHs}$ claimed to be familiar with SuDSs. Knowledge of WrGIs/SuDSs was evident in about $50 \%$ of local authorities, with French ones more updated on innovative forms of stormwater runoff management; in fact, only 30\% of Italian local authorities were knowledgeable about WrGIs/SuDSs. On the other hand, Italian consultants seem to be quite updated. We assume the same for the French region, as per similarities with the local authorities case, although our technical/scientific sample is small on the French side. 


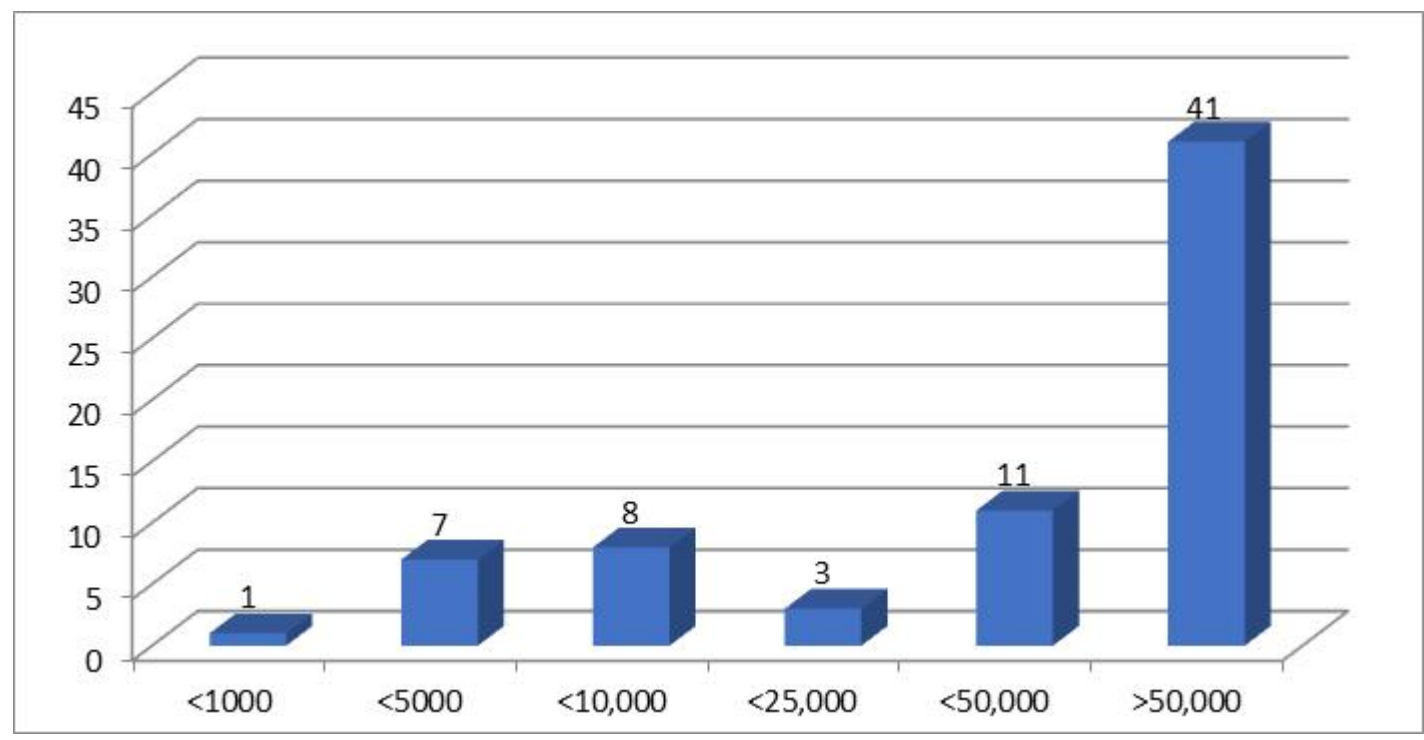

Figure 3. Frequency histogram of the number of areas in which the stakeholders act per number of inhabitants ( $x$ axis).

\subsection{Actual Behaviour}

We focus here on the answers provided by the 26 local administrations, that is, the technical SHs having the most complete information on the measures actually in place, given their decision-making role.

In order to frame the actual behaviour on the stormwater runoff management strategies adopted and already in place in the four regions, we first posed a question on the presence of conventional grey infrastructures, then on the implemented WrGIs/SuDSs. The answers show local drainage strategies still rely more frequently on separate (21 cases) than on mixed sewer systems (11). In nine areas, the two systems largely co-exist. Only four SHs declared the existence of stormwater runoff treatment systems in their area.

With regard to WrGIs/SuDSs, 18 out of 26 administrations confirmed that they are in place in their area. We found the absence of any type of SuDS in five local administrations, while in three cases the respondents were unable to provide an answer to this regard. This is somehow surprising when looking at the initial question on familiarity with WrGIs/SuDSs, where only 13 out 26 local administrations replied positively. We explain this as a result of a terminology gap in local authorities in classifying these infrastructures. This has already been highlighted in [49] and may be viewed as an example of miscommunication. In fact, familiarity with WrGIs/SuDSs is probably lower because the interviewed staff did not know the infrastructures with such definitions/terms. This in turn may be due to the fact that interest in these infrastructures is relatively new, and still not widespread in university/professional courses in the regions. Hence, staffs at local authorities, advanced in age, having also less demand and obligation for continuous learning, are not updated on the unifying background, that is recently given under the name of WrGIs/SuDSs, to infrastructures such rainwater harvesting, permeable pavements, and green roofs, that have been on the scene for decades.

The implementation of WrGIs/SuDSs is not homogenous within the investigated areas: $82 \%$ of French local administrations stated the implementation of at least one typology, while in Italy only $60 \%$ did so. With respect to the investigated Italian context, the French region of PACA seems to be more advanced in the use of WrGIs/SuDSs, showing more familiarity, and more frequent and various use of typologies. Administrations implementing SuDSs indicated the use of three different types on average. Rainwater harvesting and permeable pavements are by far the more frequently used schemes, at $21 \%$ and $14 \%$, respectively. Rare, but present, are green roofs, drainage trenches, vegetated channels, infiltration basins, and artificial wetlands. Only French local administrations stated the use of drainage trenches and green roofs (Figure 4). With this results we confirm via direct investigation 
what was found in [42] based on web-available grey literature review: WrGIs/SuDSs are fostered in both countries, but their adoption is more pronounced in the PACA region and limited in the Italian regions. We also notice that [42] does not report any pilot project in PACA, while at the same time, WrGI pilots exist in Tuscany (i.e., a large scale phytotreatment scheme near Pisa [50], and a managed aquifer recharge scheme ( a two-stage infiltration basin) in Suvereto [51]).

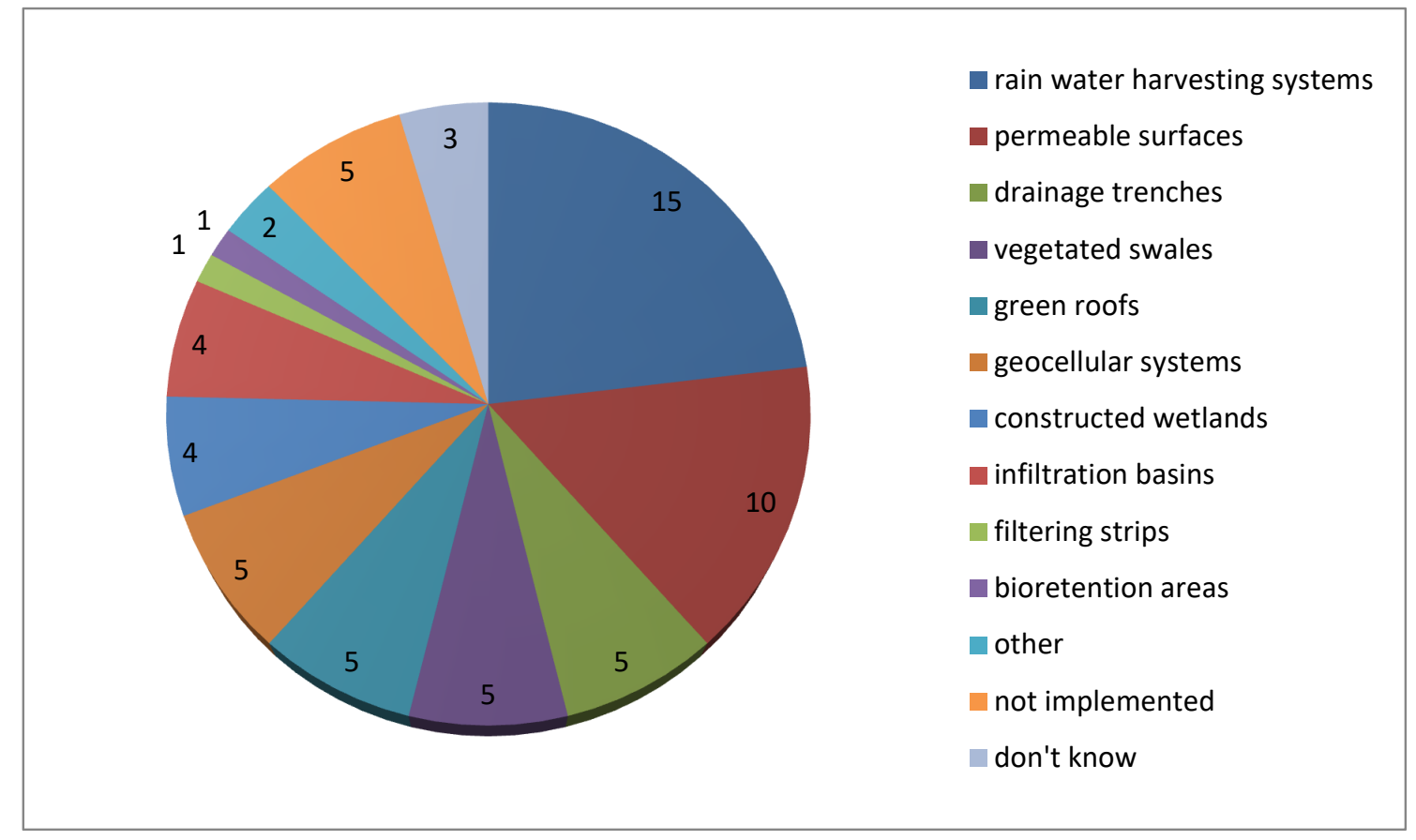

Figure 4. Type and number of WrGIs/SuDSs implemented in the four investigated regions.

Within the investigated areas, regulations supporting the adoption of WrGIs/SuDSs are still largely absent, being mentioned by only three local administrations (two in Italy and one in France; Figure 5). In such cases, the regulations supporting the use of WrGIs/SuDSs are included in the municipal urban planning regulations, or within the technical norms for flood and geomorphological risk management plans in Italy (Piani di Assetto Idrogeologico, PAI) and in water resource management plans in France (Schéma directeur d'aménagement et de gestion des eaux, SDAGE). In 17 out of 26 cases, administrations declared the absence of regulations supporting WrGIs/SuDSs and in one case they were not able to answer. Guidelines for facilitating the implementation of SuDSs are available at only five local authorities. We also notice that when asked about the presence of norms for the management of stormwater runoff, 13 administrations gave a positive answer, four mentioned guidelines, seven gave a negative answer, and one stated no knowledge about it. As WrGIs/SuDSs are rarely mentioned as effective measures then, in the investigated regions, there is a need for updating regulations and norms. It is not surprising to know that regulations on stormwater runoff management are in place at only 13 out 26 local authorities. This shows that the legal framework may constitute a barrier to WrGIs/SuDSs adoption by not expressly mentioning or giving value to their implementation. The same issue was raised in [19]. In their research, on the state of SuDSs delivery in the United Kingdom, Melville-Shreeve et al. (2018) [19] mentioned that the design and construction remain weakly regulated, citing a lack of a clear legal framework on SuDS ownership and maintenance. These authors also called for the need for a single adoption method, coordinated by the local authority, and suggested policy changes to make SuDSs obligatory. 


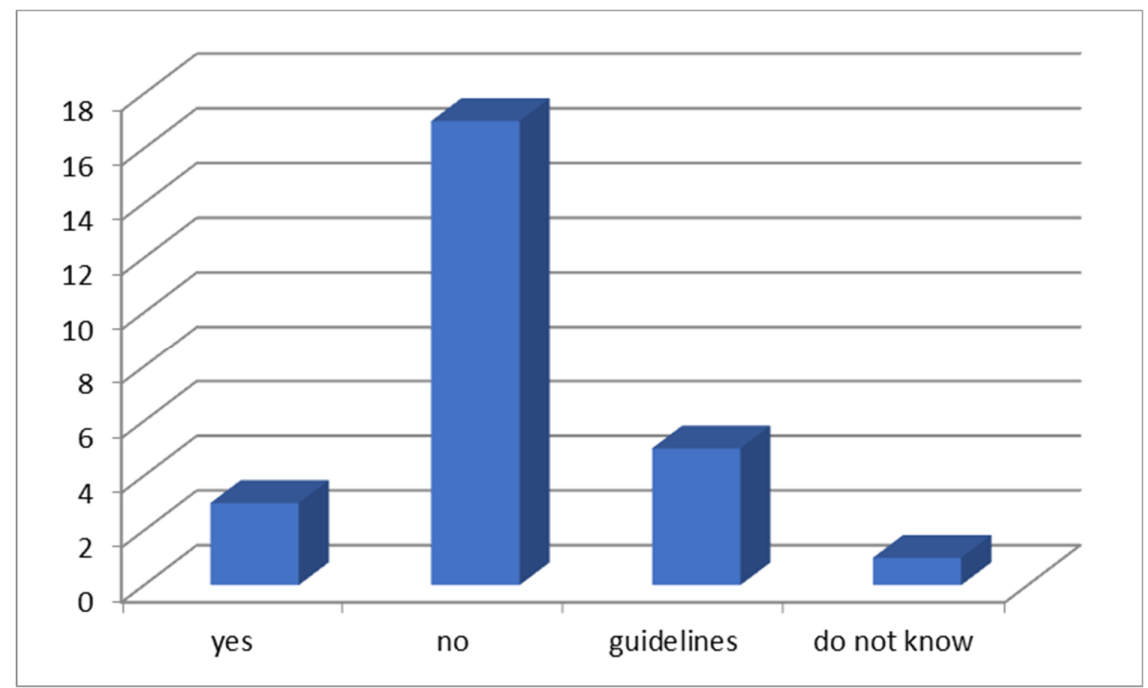

Figure 5. Presence of regulations/norms supporting the implementations of WrGIs/SuDSs.

On a more advanced level, the use of participatory processes for the planning and management of drainage systems and the implementation of WrGIs is still largely a minority at all decision-making, program, and project levels, as shown in Table 2. Both for drainage system management and implementing WrGIs/SuDSs, few administrations declared that they are using participatory processes, demonstrating still a top-down conservative approach.

Table 2. Use of participatory processes in decision-making for drainage system management and the set-up of WrGIs/SuDSs.

\begin{tabular}{ccccc}
\hline \multicolumn{5}{c}{ Participatory Processes for } \\
\hline Drainage System Management & Yes & No & Do Not know & No Answer \\
\hline At Political Level & 3 & 15 & 6 & 2 \\
At Planning Level & 3 & 16 & 6 & 1 \\
At Design Level & 6 & 13 & 6 & 1 \\
\hline Implementation of WrGIs/SuDSs & Yes & No & Do Not know & No Answer \\
At Political Level & 1 & 16 & 4 & 5 \\
At Planning Level & 1 & 17 & 4 & 4 \\
At Design Level & 1 & 17 & 4 & 4 \\
\hline
\end{tabular}

In the investigated areas, almost all the administrations mentioned that there are no fiscal or financial incentives for private entities (citizens or companies) to support or promote the management of stormwater runoff (Table 3). The same question was posed more precisely, referring to the implementation of WrGIs/SuDSs. Only two authorities in France mentioned this possibility for fiscal incentives, while no financial support is provided. It must also be noticed that we received a high rate of "do not know" and "no" answers to these two questions, about $25 \%$ and $30 \%$, respectively. The absence of fiscal and financial incentives may surely constitute a barrier to WrGIs/SuDSs uptake by private citizens and companies as also found by Tsantopoulos et al. (2018) [33].

Finally, updating strategies for urban/peri-urban flood risk management is generally perceived as highly needed by the majority of the respondents. Giving an opinion on a Likert scale from 1 (not needed) to 5 (highly needed), the median value of the answers is 5 . It is also largely recognised, by almost $80 \%$ of the respondents, that updates will need to cope with climate change and that specific measures able to adapt to climate change are needed. However, we have to mention that four local authorities did not agree, explaining the answer with the fact that the stormwater runoff management systems and strategies in place are so obsolete that they will have to be changed anyway. 
Table 3. Fiscal and financial incentives for supporting the management of stormwater runoff and the set-up of WrGIs/SuDSs).

\begin{tabular}{ccccccccc}
\hline & \multicolumn{3}{c}{ Management of Stormwater Runoff } & \multicolumn{3}{c}{ Set-Up of WrGIs/SuDSs } \\
\cline { 2 - 9 } & Yes & No & Do Not Know & No Answer & Yes & No & Do Not Know & No Answer \\
\hline Fiscal Incentive & 3 & 19 & 4 & 0 & 2 & 18 & 5 & 1 \\
Financial Incentive & 1 & 17 & 1 & 7 & 0 & 15 & 3 & 8 \\
\hline
\end{tabular}

\subsection{Attitude towards WrGIs/SuDSs}

We present here the results of the survey for the whole number of stakeholders interviewed, not only the public local authorities. In the target areas, we recorded a large, but variable, interest in the use of innovative measures such as WrGIs/SuDSs. The interest, expressed on a scale from 1 to 5 , stands on a median and a 75th percentile of 4 , while the value of the 25 th percentile is 2 .

The types of WrGIs/SuDSs considered as the most interesting for drainage system updates are again rainwater harvesting systems and permeable pavements (Figure 6). Drainage trenches, vegetated channels, and infiltration basins are considered interesting by about half of the respondents, but their effectiveness and reliability seems not to be fully understood. This is probably due to the absence/or relatively new presence of successful pilots or demonstrative schemes in the investigated areas, which could raise the confidence of the stakeholders. However, the interest in these types of GIs for future drainage management may indicate an initial strategic and systematic vision of the implementation of WrGIs/SuDSs at the network level: vegetated canals and trenches are linear drainage elements, while the basins and wetlands are points of delivery for surface runoff.

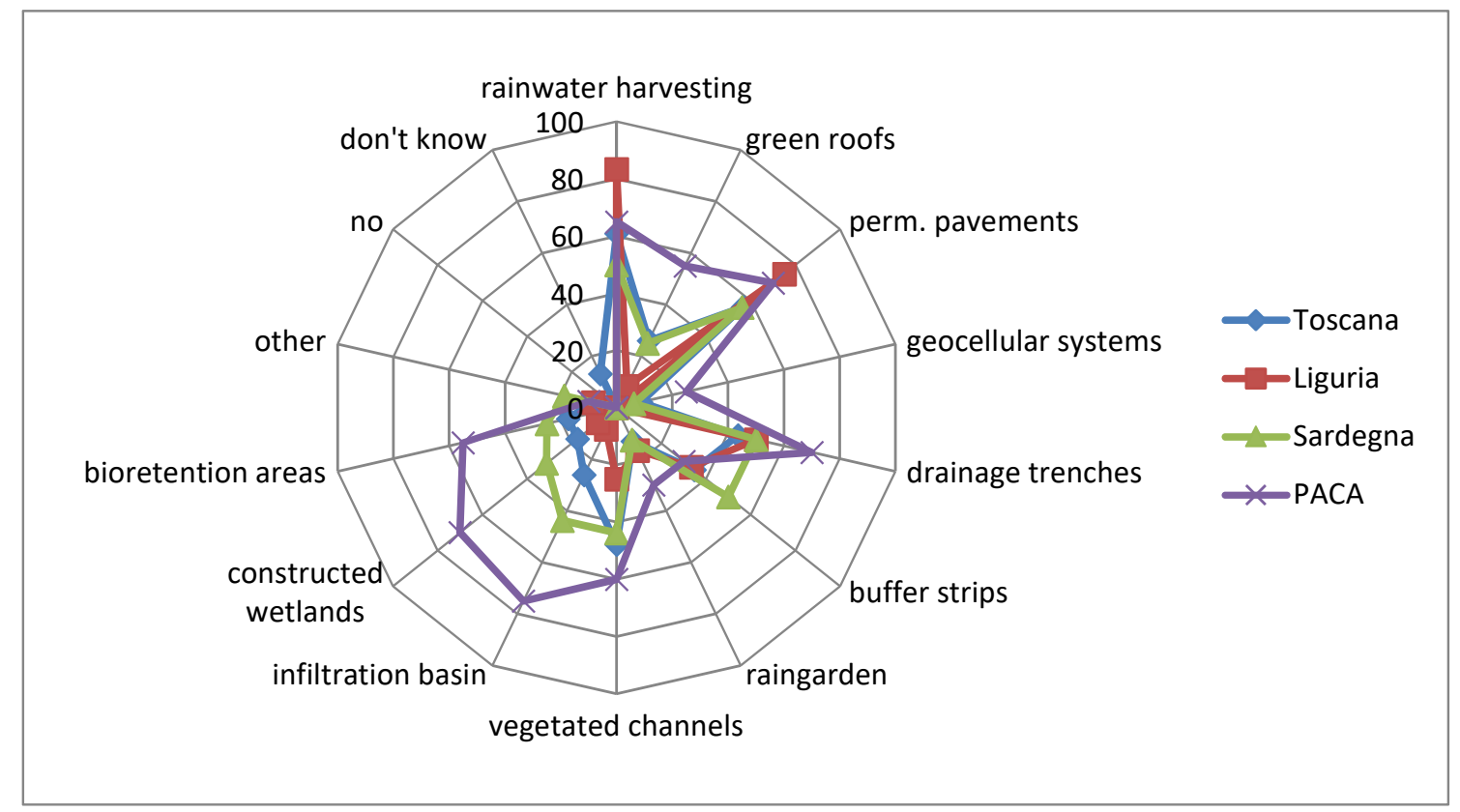

Figure 6. Stakeholder interest in different types of WrGIs/SuDSs as a percentage of those interviewed.

Stakeholders were asked for which services, in their opinion, WrGIs/SuDSs were the most suitable. We proposed seven predefined voices: (1) urban and peri-urban flood risk control (HR), (2) protection against erosion (EC), (3) increase in water resource (WS), (4) pollution control (PC), (5) environmental restoration (ER), (6) recreational service (RV), and (7) economic efficiency (EE). The interviewees expressed their opinion, assigning to each service a value on a scale between 1 (the least important element) and 7 (most important). The results (Figure 7) show that the WrGIs/SuDSs are generally considered relevant for providing HR services, which obtained the highest median (6.5) and a 25th 
percentile of 5 . Half of the interviewees assigned to HR values between 5 and 7 . The second theme for reliability is ER, with a median of 5 , a 25 th percentile of 4 , and a 75 th of 6 . EC obtained similar values, but was characterised by less homogeneity, with a 25th percentile of 3 . WS, PC, RV, and EE obtained equal medians, but different distributions. In particular, WS and RV are the services to which lower values were assigned, $50 \%$ of the time between 2 and 5 .

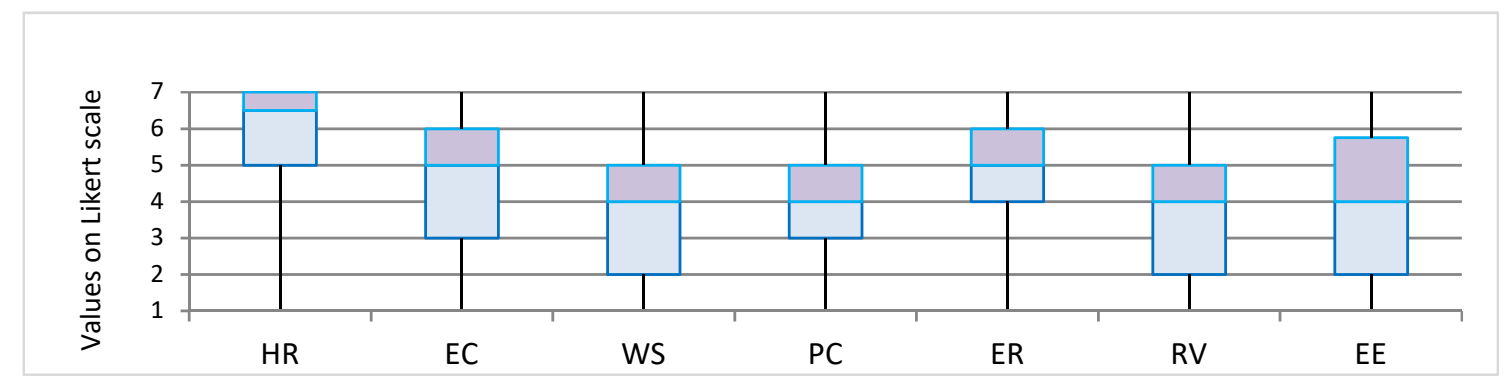

Figure 7. Box-plot for the utility of WrGIs/SuDSs perceived by stakeholders on a Likert scale from 1 (very low) to 7 (very high): HR (flood risk control), EC (erosion control), WS (water storage), PC (pollution control), ER (environmental restoration), RV (recreational value), EE (economic efficiency).

These answers partly confirm the stakeholders interest for types of WrGIs/SuDSs aiming at mitigating surface runoff (permeable pavements and rainwater harvesting systems). Indeed, the aforementioned preference for rainwater harvesting systems may raise interest on the use of SuDSs for water resource management, while from the answers we understand this water supply service seems not to be fully recognised.

With respect to the cost of the construction and maintenance of WrGIs/SuDSs compared to conventional infrastructures, in more than $50 \%$ of the cases, stakeholders say they have no information for answering these questions (Figure 8). However, although the costs for both WrGI/SuDS construction and maintenance are higher, in about 35\% of the cases, the SHs believe the benefits overwhelm the cost increase. A small number of stakeholders consider the costs of WrGI/SuDS construction and maintenance to be even less expensive (ten and seven, respectively). The opinion of the subjects who considered the construction and maintenance costs to be higher than those of the grey infrastructures is probably influenced by their lack of familiarity with these interventions, which have not yet been carried out systematically. To support the cost-benefits evaluation of these infrastructures, decision support systems exist that allow for the comparison of different drainage scenarios, conventional or with the use of WrGIs/SuDSs, on construction and maintenance costs, energy consumption, greenhouse gas emissions, and the provision of ecosystem services (i.e., E²STORMED; [52]).

When asked about the potential interest for the implementation of WrGIs/SuDSs in the investigated areas, 39\% answered that there is interest for this kind of infrastructure. The rest of the stakeholders answered that the general lack of interest is related above all to the still sporadic local knowledge on these systems (27\%; Figure 9$)$. A further $10 \%$ explicitly prefer traditional systems because, it was said, they are well known and reliable. This stresses again the importance of demonstration pilots and capacity building. However, the construction and maintenance costs and efforts are still perceived as limitations to the diffusion of these systems by $24 \%$ of the respondents. These results seem to reduce, in the investigated domain, the importance of one of the factors limiting the use of WrGIs/SuDSs, as described in the literature (see $[53,54]$ ): the strong trust by administration staff towards conventional engineering practices. In fact, only seven out of 71 stakeholders indicated the reliability of conventional systems as a limiting factor to the implementation of WrGIs/SuDSs. 


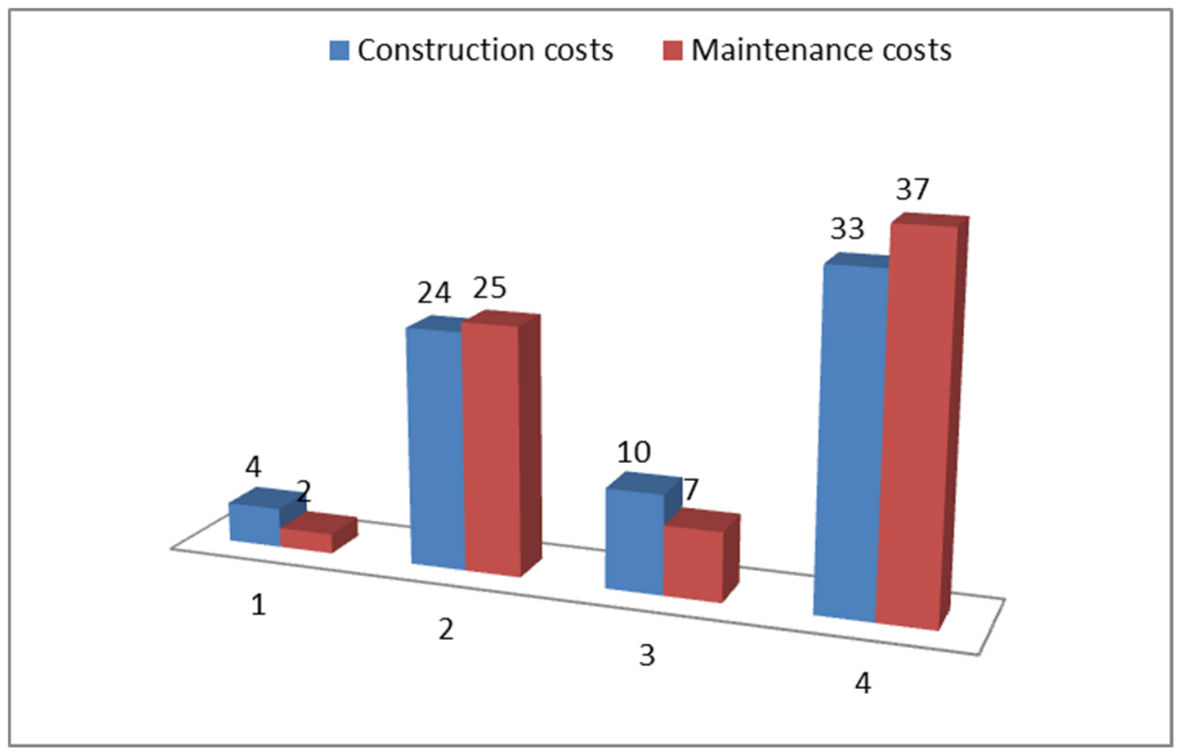

Figure 8. Number of answers for the question on whether cost of construction and maintenance for WrGIs/SuDSs vs. conventional infrastructures may be (1) higher and the benefits do not compensate for the increase; (2) higher but the benefits compensate for the increase (3) lower; (4) do not know.

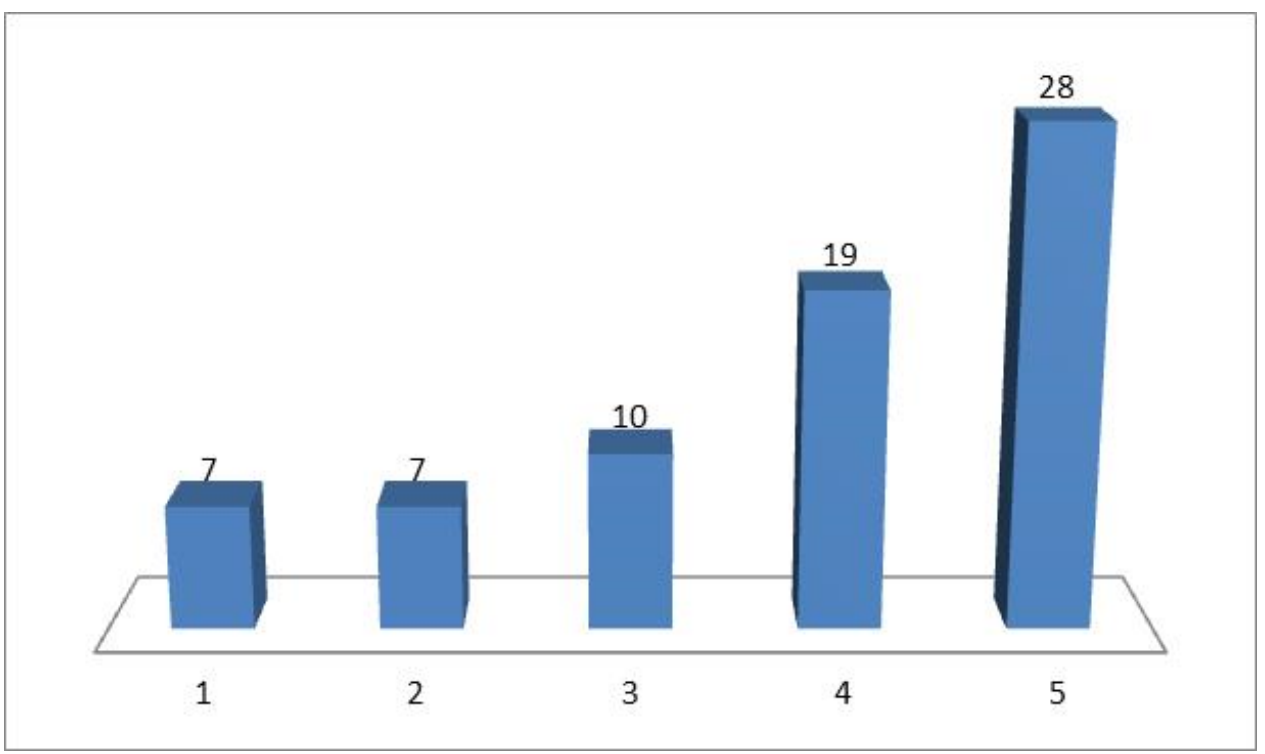

Figure 9. Causes for reduced local interest in WrGIs/SuDSs: (1) traditional systems are reliable and recognised; (2) the long-term maintenance costs of WrGIs/SuDSs are considered problematic; (3) the construction costs of WrGIs/SuDSs are considered higher than those of the grey infrastructures; (4) little general interest in the area for WrGIs/SuDSs; (5) there is interest in WrGIs/SuDSs in the area.

Finally, respondents indicated that the dissemination of information can be an effective tool to increase interest in these systems, as well as fiscal and financial incentives (Figure 10). All the stakeholders agreed that information activities and campaigns may support the uptake of new green measures for stormwater runoff management. However, they believed that financial and fiscal incentives might be more relevant for stimulating the adoption of GIs. 


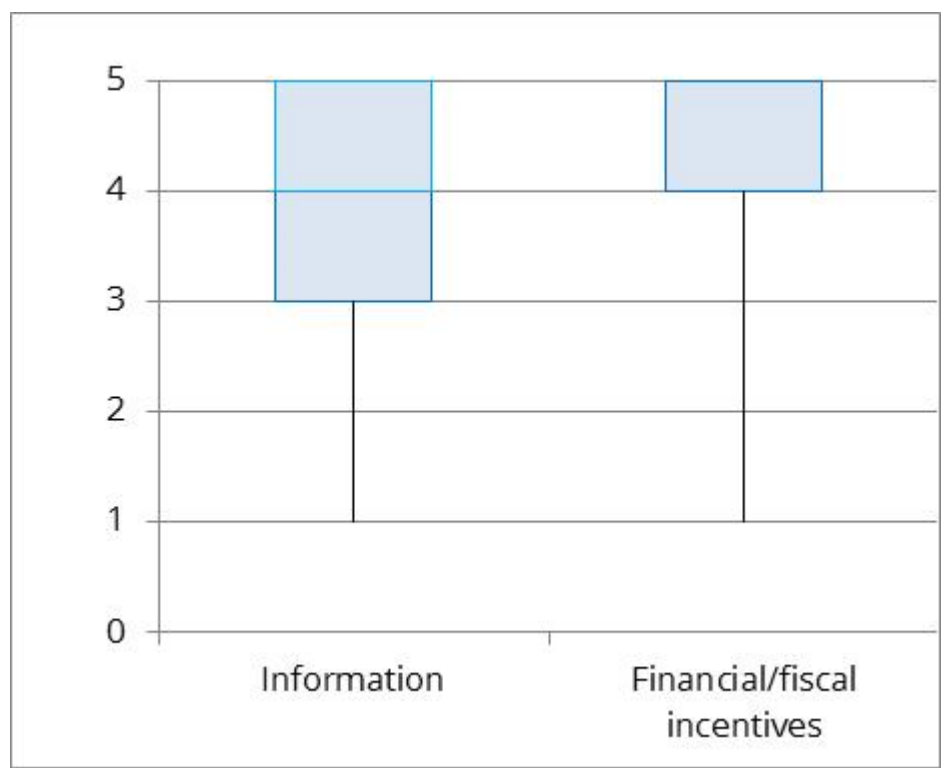

Figure 10. The importance of effective tools to increase interest in WrGIs/SuDSs.

\subsection{Planners' and Prescribers' Opinions}

The stakeholders' opinions were compared by dividing them into two populations of comparable size called Planners and Prescribers. The comparison was made between the answers provided by the two populations to the questions on: (i) the need for updating stormwater management strategies; (ii) is there interest in SuDSs in your area?; (iii) do you believe information activities on SuDSs may support their uptake?; and iv) do you believe fiscal and financial incentives on WrGIs/SuDSs may help their uptake? Given the ordered variables, the non-parametric Mann-Whitney $U$ test with a significance of $p<0.05$ was used. The results (Table 4) indicate a general uniformity of opinions between Planners and Prescribers, with reduced differences that are not statistically significant. The only differences actually measured are in the perception of the interest in WrGIs/SuDSs in the target areas and in the usefulness of tax and financial incentives. In the first case, the Prescribers believe that there is a reduced general interest, compared to the Planners' opinion, with medians of 3 and 4 respectively, and $p<0.0003$. Tax and financial incentives to spread the use of SuDSs are considered more efficient by Prescribers (5) than by Planners (4), with $p<0.039$. Moreover, the same test was run to analyse the two populations' view on the services WrGIs/SuDSs may provide. In this case there were also no statistically significant differences.

Table 4. Results of the comparisons of questions with an ordered scale from 1 to 5 between Planners and Prescribers with a Mann-Whitney U test.

\begin{tabular}{|c|c|c|c|c|}
\hline & \multicolumn{2}{|c|}{$\begin{array}{l}\text { Need for Updating Stormwater } \\
\text { Management Strategies? }\end{array}$} & \multicolumn{2}{|c|}{ Is there an Interest in SuDSs? } \\
\hline & Median & Different Pop? $(p<0.05)$ & Median & Different Pop.? $(p<0.05)$ \\
\hline Planners & 4.5 & \multirow{2}{*}{ No $(p=0.36)$} & 4 & \multirow{2}{*}{ Yes $(p=0.0007)$} \\
\hline \multirow[t]{3}{*}{ Prescribers } & 5 & & 3 & \\
\hline & \multicolumn{2}{|c|}{$\begin{array}{l}\text { Do You Believe Information Activities on } \\
\text { WrGIs/SuDSs May Help Their Uptake? }\end{array}$} & \multicolumn{2}{|c|}{$\begin{array}{l}\text { Do You Believe Fiscal and Financial Incentives } \\
\text { on WrGIs/SuDSs May Help Their Uptake? }\end{array}$} \\
\hline & Median & Different Pop.? $(p<0.05)$ & Median & Different Pop.? $(p<0.05)$ \\
\hline Planners & 4 & \multirow{2}{*}{ No $(p=0.52)$} & 4 & \multirow{2}{*}{ Yes $(p=0.039)$} \\
\hline Prescribers & 4 & & 5 & \\
\hline
\end{tabular}




\section{Conclusions}

In this paper we investigated the actual behaviour and attitude of 71 relevant stakeholders towards WrGIs/SuDSs in three Italian regions (Toscana, Liguria, and Sardegna) and one French region (Provence-Alpes-Côte d'Azur) in the northwestern Mediterranean. Our investigation reached a wide range of technical stakeholders, including authorities not only dealing with stormwater runoff management, but also with resilience to current climate changes, and in particular water resource management. We also involved a variety of qualified stakeholders for their scientific and technical knowledge (academics and practitioners) related to WrGI/SuDS themes, together with associations interested in the topic and representing the local areas. However, our investigated sample does not include representatives of the local authorities from some of the large cities in the region, such as Florence and Genova. Local representatives from academia, chartered professionals, or relevant companies were interviewed from these areas. Then, we believe that given the limited adoption of WrGIs/SuDSs in these cities, as for others in the sample, the dimension of the urban area does not constitute an element that may change the attitude or behaviour in local authorities.

When framing the present conditions, $53 \%$ of the stakeholders show familiarity with the concept of WrGIs/SuDSs, but at the same time we identified a large number of stakeholders (47\%) with limited or even no knowledge on the matter. The implementation of WrGIs/SuDSs is claimed by about $80 \%$ of French local authorities and $60 \%$ of Italian ones. We also noticed that many of the respondents were not aware of the unifying background that has recently been given under the name of WrGIs/SuDSs. Compared to PACA, we noticed a potential reduced environmental sensitivity of Italian local administrations and the low propensity for innovation and knowledge of information and models coming from northern EU. The French region of PACA also seems to be advanced on the adoption of WrGIs/SuDSs, presenting the implementation of more typologies, although [42] does not report any pilot project in that area, while pilots exist in the Italian areas. Generally, the outcomes of our survey directly confirm the lower attention paid to WrGIs/SuDSs in Mediterranean countries compared to northern European ones, as also stated in [42,55].

Stakeholders consider systems they are already familiar with (i.e., rainwater harvesting systems, permeable pavements) as the most interesting for implementation. Undoubtedly, this evidence calls for the need for demonstration pilots of the reliability of less common infrastructures. A positive aspect is that about $35 \%$ of the SHs fully understand the importance of the benefits of WrGI/SuDS implementation, although the construction and maintenance costs might be larger than for conventional infrastructures. For the services these infrastructures may provide, the stakeholders are mainly focused on traditional flood risk prevention, and secondly on environmental restoration, while the potential increase in water availability and pollution prevention services are not considered of particular interest.

The survey allowed us to define the main barriers and limitations of technical and social nature to WrGI/SuDS uptake in the investigated regions. For the first one, the main limitation to WrGI/SuDS adoption is explained by an absence of knowledge of these solutions (27\%). Uncertainties on the design, construction, and maintenance costs are also perceived as main barriers: more than $50 \%$ of the stakeholders declared they have no elements to judge the cost of the construction and maintenance of WrGIs/SuDSs with respect to conventional infrastructures. To this aim, software tools for aided decision-making may be valuable tools for performing such analysis [52]. They should be used for comparing conventional and WrGI/SuDS interventions, not only on the construction and maintenance costs, but also on the energy consumption, greenhouse gas emissions, and the provision of ecosystem services of each planned infrastructure.

Regulations supporting the adoption of WrGIs/SuDSs are still largely absent in the four regions (only present in three out of 26 local authorities) and guidelines for their implementation are only available at five local authorities. This makes it difficult to plan these innovative infrastructures following often old bodies of norms and regulations. As in the areas of Liguria, Sardegna, PACA, and Toscana there is a common need for updating stormwater runoff management strategies and drainage systems to adapt to climate change, there may be space to include WrGIs/SuDSs into new 
planning instruments. At the same time, participatory processes are run in projects (i.e., the EU-MED Programme E2STORMED project [52], or the TRIG-Eau project [41]) where cooperation between academia/research and local authorities takes place, but they are completely lacking outside this framework, highlighting dominant top-down approaches. Fiscal or financial incentives to support the implementation of WrGIs/SuDSs by private citizens and companies are also missing or not advertised adequately, but a central element in the transition to GIs, and a barrierto be removed.

However, $10 \%$ of the stakeholders explicitly prefer traditional systems because they believe these are well known and reliable. Additionally, questions about infiltrating low-quality, if not polluted, water in underlying aquifers arose [56]; these issues are at present not really considered in the literature aside from general considerations i.e., [57]. A general framework for risk assessment during the design phase should be set up, such as the one described in [58] for managed aquifer recharge. This again stresses the need for reliable (in the sense of monitored) demonstrators, a fundamental step to increase confidence in such infrastructures.

All the stakeholders agree that information activities and campaigns may support the uptake of WrGIs/SuDSs. Capacity building, in the form of short courses, workshops, and webinars for practitioners or technicians from public authorities, but also to policy/decision-makers, is a key cornerstone for the transition to adaptive stormwater management. This is especially true if such training experiences are based on the above-mentioned experimental demonstrators, where data are gathered and rigorously analysed by cooperative work performed jointly by the research and the public/private environment, and potentially supported by citizen science activities.

Our results confirm the direct voices of the main actors involved the conclusions of Gimenez-Maranez et al. 2020 [42], results only based on web-searches. WrGIs/SuDSs are increasingly being supported in France and Italy, but in the investigated regions, their adoption is more advanced in the PACA region and still limited in the Italian regions. All the above-mentioned tools and soft measures, tailored to the needs of the local areas, in our opinion, may contribute to support for the implementation of WrGIs/SuDSs, especially in view of adapting Mediterranean territories to the challenges posed by climate change.

Author Contributions: Conceptualization, R.R.; methodology, R.R.; validation, S.M.P.; formal analysis, S.M.P.; investigation, S.M.P.; writing-original draft preparation, R.R., S.M.P.; writing-review and editing, R.R.; supervision, R.R.; funding acquisition, R.R. All authors have read and agreed to the published version of the manuscript.

Funding: The research was co-financed by the European Regional Development Fund INTERREG MARITTIMO IT-FR, project TRIG-Eau (Transfrontalierità, Resilienza, Innovazione e Governance per la prevenzione del rischio idrogeologico), CUP G96J16001250005.

Acknowledgments: We wish to acknowledge also the colleagues Anna Palla and Ilaria Gnecco (Dipartimento di Ingegneria Civile, Chimica e Ambientale, Università di Genova) for suggestions on the initial version of the questionnaire and AVITEM (Agence des Villes et Territoires Méditerranées Durables). The latter contributed in defining questions on legislation and the participatory processes. We also wish to acknowledge Andrea Mazzuoli, former post-graduate scholarship at Scuola Superiore Sant'Anna, and the direction and staff of the TRIG-Eau project coordinating team at Consorzio di Bonifica 5 Toscana Costa for their support.

Conflicts of Interest: The authors declare no conflict of interest.

\section{References}

1. Campisano, A.; Butler, D.; Ward, S.; Burns, M.J.; Friedler, E.; DeBusk, K.; Fisher-Jeffes, L.N.; Ghisi, E.; Rahman, A.; Furumai, H.; et al. Urban rainwater harvesting systems: Research, implementation and future perspectives. Water Res. 2017, 115, 195-209. [CrossRef]

2. Palla, A.; Gnecco, I.; La Barbera, P. The impact of domestic rainwater harvesting systems in storm water runoff mitigation at the urban block scale. J. Environ. Manag. 2017, 191, 297-305. [CrossRef]

3. Dillon, P.; Stuyfzand, P.; Grischek, T.; Lluria, M.; Pyne, R.D.G.; Jain, R.C.; Bear, J.; Schwarz, J.; Wang, W.; Fernandez, E.; et al. Sixty years of global progress in managed aquifer recharge. Hydrogeol. J. 2019, 27, 1-30. [CrossRef] 
4. Maiolo, M.; Pirouz, B.; Bruno, R.; Palermo, S.A.; Arcuri, N.; Piro, P. The role of the extensive green roofs on decreasing building energy consumption in the mediterranean climate. Sustainability 2020, 12, 359. [CrossRef]

5. Shafique, M.; Kim, R.; Rafiq, M. Green roof benefits, opportunities and challenges-A review. Renew. Sustain. Energy Rev. 2018, 90, 757-773. [CrossRef]

6. Scholz, M.; Grabowiecki, P. Review of permeable pavement systems. Build. Environ. 2007, 42, 3830-3836. [CrossRef]

7. Thomas, A.; Haselbach, L.; Poor, C.; Freimund, M. Long-term metal retention performance of media filter drains for stormwater management. Sustainability 2015, 7, 3721-3733. [CrossRef]

8. Flanagan, K.; Branchu, P.; Ramier, D.; Gromaire, M.-C. Evaluation of the relative roles of a vegetative filter strip and a biofiltration swale in a treatment train for road runoff. Water Sci. Technol. 2017, 75, 987-997. [CrossRef] [PubMed]

9. Revitt, D.M.; Ellis, J.B.; Lundy, L. Assessing the impact of swales on receiving water quality. Urban Water J. 2017, 14, 839-845. [CrossRef]

10. Boano, F.; Caruso, A.; Costamagna, E.; Ridolfi, L.; Fiore, S.; Demichelis, F.; Galvão, A.; Pisoeiro, J.; Rizzo, A.; Masi, F. A review of nature-based solutions for greywater treatment: Applications, hydraulic design, and environmental benefits. Sci. Total Environ. 2020, 711, 134731. [CrossRef]

11. Barbagli, A.; Jensen, B.N.; Raza, M.; Schueth, C.; Rossetto, R. Assessment of soil buffer capacity on nutrients and pharmaceuticals in nature-based solution applications. Environ. Sci. Pollut. Res. 2019, 26, 759-774. [CrossRef] [PubMed]

12. Quinn, R.; Dussaillant, A. Predicting infiltration pollutant retention in bioretention sustainable drainage systems: Model development and validation. Hydrol. Res. 2014, 45, 855-867. [CrossRef]

13. Special Issue "Sustainable Drainage Systems". Available online: https://www.mdpi.com/journal/water/ special_issues/SuDS (accessed on 12 May 2020).

14. Eger, C.G.; Chandler, D.G.; Driscoll, C.T. Hydrologic processes that govern stormwater infrastructure behaviour. Hydrol. Process. 2017, 31, 4492-4506. [CrossRef]

15. Fenner, R.A. Spatial Evaluation of Multiple Benefits to Encourage Multi-Functional Design of Sustainable Drainage in Blue-Green Cities. Water 2017, 9, 953. [CrossRef]

16. Xia, J.; Zhang, Y.; Xiong, L.; He, S.; Wang, L.; Yu, Z. Opportunities and challenges of the Sponge City construction related to urban water issues in China. Sci. China Earth Sci. 2017, 60, 652-658. [CrossRef]

17. Pappalardo, V.; La Rosa, D.; Campisano, A.; La Greca, P. The potential of green infrastructure application in urban runoff control for land use planning: A preliminary evaluation from a southern Italy case study. Ecosyst. Serv. 2017, 26, 345-354. [CrossRef]

18. Åstebøl, S.O.; Hvitved-Jacobsen, T.; Simonsen, Ø. Sustainable stormwater management at Fornebu-From an airport to an industrial and residential area of the city of Oslo, Norway. Sci. Total Environ. 2004, 334-335, 239-249.

19. Melville-Shreeve, P.; Cotterill, S.; Grant, L.; Arahuetes, A.; Stovin, V.; Farmani, R.; Butler, D. State of SuDS delivery in the United Kingdom. Water Environ. J. 2018, 32, 9-16. [CrossRef]

20. Perales-Momparler, S.; Andrés-Doménech, I.; Hernández-Crespo, C.; Vallés-Morán, F.; Martín, M.; Escuder-Bueno, I.; Andreu, J. The role of monitoring sustainable drainage systems for promoting transition towards regenerative urban built environments: A case study in the Valencian region, Spain. J. Clean. Prod. 2017, 163, S113-S124. [CrossRef]

21. Gimenez-Maranges, M.; Breuste, J.; Hof, A. Sustainable Drainage Systems for transitioning to sustainable urban flood management in the European Union: A review. J. Clean. Prod. 2020, 255, 120191. [CrossRef]

22. Gryseels, M. Relevance of the Concept of Ecosystem Services in the Practice of Brussels Environment (BE). In Ecosystem Services: Global Issues, Local Practices; Elsevier: CA, USA, 2014. Available online: https://www.elsevier.com/books/ecosystem-services/jacobs/978-0-12-419964-4 (accessed on 20 May 2020).

23. Communication from the Commission to the European Parliament, the Council, the European Economic and Social Committee and the Committee of the Regions Green Infrastructure (GI)—Enhancing Europe's Natural Capital; COM/2013/0249 Final; European Union: Brussels, Belgium, 2013. Available online: https://eur-lex.europa.eu/ legal-content/EN/TXT/?uri=CELEX\%3A52013DC0249 (accessed on 20 May 2020). 
24. Faivre, N.; Fritz, M.; Freitas, T.; de Boissezon, B.; Vandewoestijne, S. Nature-Based Solutions in the EU: Innovating with nature to address social, economic and environmental challenges. Environ. Res. 2017, 159, 509-518. [CrossRef] [PubMed]

25. Ferguson, B.C.; Frantzeskaki, N.; Brown, R.R. A strategic program for transitioning to a Water Sensitive City. Landsc. Urban Plan. 2013, 117, 32-45. [CrossRef]

26. Ma, Y.; Jiang, Y.; Swallow, S. China's sponge city development for urban water resilience and sustainability: A policy discussion. Sci. Total Environ. 2020, 729, 139078. [CrossRef] [PubMed]

27. Demuzere, M.; Orru, K.; Heidrich, O.; Olazabal, E.; Geneletti, D.; Orru, H.; Bhave, A.G.; Mittal, N.; Feliu, E.; Faehnle, M. Mitigating and adapting to climate change: Multi-functional and multi-scale assessment of green urban infrastructure. J. Environ. Manag. 2014, 146, 107-115. [CrossRef]

28. EEA Exploring Nature-Based Solutions. The Role of Green Infrastructure in Mitigating the Impacts of Weatherand Climate Change-Related Natural Hazards; EEA Technical Report No 12/2015 ISSN 1725-2237; European Environment Agency: Copenhagen, Denmark, 2015. Available online: https:/www.eea.europa.eu/publications/ exploring-nature-based-solutions-2014 (accessed on 20 May 2020).

29. Moore, T.L.; Gulliver, J.S.; Stack, L.; Simpson, M.H. Stormwater management and climate change: Vulnerability and capacity for adaptation in urban and suburban contexts. Clim. Chang. 2016, 138, 491-504. [CrossRef]

30. Benedict, M.A.; McMahon, E.T. Green Infrastructure: Linking Landscapes and Communities; Island Press: Washington, DC, USA, 2006; ISBN1 13: 978-1559635585. ISBN2 10: 1559635584.

31. Barnhill, K.; Smardon, R. Gaining ground: Green infrastructure attitudes and perceptions from stakeholders in Syracuse, New York. Environ. Pract. 2012, 14, 6-16. [CrossRef]

32. Everett, G.; Lamond, J.E.; Morzillo, A.T.; Matsler, A.M.; Chan, F.K.S. Delivering Green Streets: An exploration of changing perceptions and behaviours over time around bioswales in Portland, Oregon. J. Flood Risk Manag. 2018, 11, S973-S985. [CrossRef]

33. Tsantopoulos, G.; Varras, G.; Chiotelli, E.; Fotia, K.; Batou, M. Public perceptions and attitudes toward green infrastructure on buildings: The case of the metropolitan area of Athens, Greece. Urban For. Urban Green. 2018, 34, 181-195. [CrossRef]

34. Sañudo-Fontaneda, L.A.; Robina-Ramírez, R. Bringing community perceptions into sustainable urban drainage systems: The experience of Extremadura, Spain. Land Use Policy 2019, 89, 104251. [CrossRef]

35. Sturiale, L.; Scuderi, A. The evaluation of green investments in urban areas: A proposal of an eco-social-green model of the city. Sustainability 2018, 10, 4541. [CrossRef]

36. Venkataramanan, V.; Lopez, D.; McCuskey, D.J.; Kiefus, D.; McDonald, R.I.; Miller, W.M.; Packman, A.I.; Young, S.L. Knowledge, attitudes, intentions, and behavior related to green infrastructure for flood management: A systematic literature review. Sci. Total Environ. 2020, 720, 137606. [CrossRef]

37. Zuniga-Teran, A.A.; Staddon, C.; de Vito, L.; Gerlak, A.K.; Ward, S.; Schoeman, Y.; Hart, A.; Booth, G. Challenges of mainstreaming green infrastructure in built environment professions. J. Environ. Plan. Manag. 2020, 63, 710-732. [CrossRef]

38. Cannas, I.; Lai, S.; Leone, F.; Zoppi, C. Green infrastructure and ecological corridors: A regional study concerning Sardinia. Sustainability 2018, 10, 1265. [CrossRef]

39. Bottalico, F.; Travaglini, D.; Chirici, G.; Garfi, V.; Giannetti, F.; De Marco, A.; Fares, S.; Marchetti, M.; Nocentini, S.; Paoletti, E.; et al. A spatially-explicit method to assess the dry deposition of air pollution by urban forests in the city of Florence, Italy. Urban For. Urban Green. 2017, 27, 221-234. [CrossRef]

40. Perini, K.; Magliocco, A. Urban sustainable development in the Mediterranean area: The case of Sestri Ponente, Genoa. In Mediterranean Green Buildings and Renewable Energy; Selected Papers from the World Renewable Energy Network's Med Green Forum; Springer: Cham, Switzerland, 2017; pp. 599-607.

41. Rossetto, R.; Piacentini, S.M. Infrastrutture Blu/Verdi e Misure Non Strutturali per la Mitigazione del Rischio Idraulico in Ambiente Urbano e Peri-Urbano. Esempi di Buone Pratiche; INTERREG-MARITTIMO ITALIA FRANCIA T.R.I.G.-Eau (CUP G96J16001250005). Available online: http://interreg-maritime.eu/web/t.r.i.g-eau (accessed on 20 May 2020).

42. Gimenez-Marangesa, M.; Pappalardo, V.; La Rosa, D.; Breustea, J.; Hofa, A. The transition to adaptive storm-water management: Learning from existing experiences in Italy and Southern France. Sustain. Cities Soc. 2020, 55, 102061. [CrossRef] 
43. San Francisco Water Power Sewer San Francisco Stormwater Design Guidelines: Fact Sheets. San Francisco Public Utilities Commission. Available online: http://sfwater.org/modules/showdocument.aspx?documentid=9071 (accessed on 20 May 2020).

44. CDHS-VBDS. A Preliminary Assessment of Vectors Associated with Stormwater Management Structures in the United States-A Nationwide Vector Control Perspective; CDHS-VBDS: CA, USA, 2001. Available online: http://www2.dot.ca.gov/hq/env/stormwater/special/newsetup/_pdfs/new_technology/CTSW-RT01-050/AppendixE/09_DHS_Out-of-State_Survey.pdf (accessed on 31 March 2020).

45. Balram, S.; Dragicevic, S. Attitudes toward urban green spaces: Integrating questionnaire survey and collaborative GIS techniques to improve attitude measurements. Landsc. Urban Plan. 2005, 71, 147-162. [CrossRef]

46. Baptiste, A.; Foley, C.; Smardon, R. Understanding urban neighborhood differences in willingness to implement green infrastructure measures: A case study of Syracuse, NY. Landsc. Urban Plan. 2015, 136, 1-12. [CrossRef]

47. Camps-Calvet, M.; Langemeyer, J.; Calvet-Mir, L.; Gomez-Baggethun, E. Ecosystem services provided by urban gardens in Barcelona, Spain: Insights for policy and planning. Environ. Sci. Policy 2016, 62, 14-23. [CrossRef]

48. Nanekely, M.; Scholz, M.; Al-Faraj, F. Strategic Framework for Sustainable Management of Drainage Systems in Semi-Arid Cities: An Iraqi Case Study. Water 2016, 8, 406. [CrossRef]

49. Fletcher, T.D.; Shuster, W.; Hunt, W.F.; Ashley, R.; Butler, D.; Arthur, S.; Trowsdale, S.; Barraud, S.; Semadeni-Davies, A.; Bertrand-Krajewski, J.-L.; et al. SUDS, LID, BMPs, WSUD and more-The evolution and application of terminology surrounding urban drainage. Urban Water J. 2015, 12, 525-542. [CrossRef]

50. Giannini, V.; Bertacchi, A.; Bonari, E.; Silvestri, N. Rewetting in Mediterranean reclaimed peaty soils and its potential for phyto-treatment use. J. Environ. Manag. 2018, 208, 92-101. [CrossRef] [PubMed]

51. Rossetto, R.; De Filippis, G.; Piacentini, S.M.; Matani, E.; Sabbatini, T.; Fabbrizzi, A.; Ravenna, C.; Benucci, C.; Pacini, F.; Masi, M.; et al. Using flood water in Managed Aquifer Recharge schemes as a solution for groundwater management in the Cornia valley (Italy). Geophys. Res. Abstr. 2018, 20, 12861.

52. Morales-Torres, A.; Escuder-Bueno, I.; Andrés-Doménech, I.; Perales-Momparler, S. Decision Support Tool for energy-efficient, sustainable and integrated urban stormwater management. Environ. Model. Softw. 2016, 84, 518-528. [CrossRef]

53. Carlet, F. Understanding attitudes toward adoption of green infrastructure: A case study of US municipal officials. Environ. Sci. Policy 2015, 51, 65-76. [CrossRef]

54. Matthews, T.; Lo, A.Y.; Byrne, J.A. Reconceptualizing green infrastructures for climate change adaptation: Barriers to adoption and drivers for uptake by spatial planners. Landsc. Urban Plan. 2015, 138, 155-163. [CrossRef]

55. Castro-Fresno, D.; Andrés-Valeri, V.C.; Sañudo-Fontaneda, L.A.; Rodriguez-Hernandez, J. Sustainable drainage practices in Spain, specially focused on pervious pavements. Water 2013, 5, 67-93. [CrossRef]

56. Jefferies, C.; Napier, F. Source Control Pollution in Sustainable Drainage: Final Report. SNIFFER Final Report. Available online: https://rke.abertay.ac.uk/en/publications/source-control-pollution-in-sustainable-drainagefinal-report (accessed on 14 May 2020).

57. UK Groundwater Forum. Surface Water Flooding: Sustainable Drainage to the Ground. Available online: http://www.groundwateruk.org/Groundwater-issues-SUDS.aspx (accessed on 14 May 2020).

58. Rodríguez-Escales, P.; Canelles, A.; Sanchez-Vila, X.; Folch, A.; Kurtzman, D.; Rossetto, R.; Fernández-Escalante, E.; Lobo-Ferreira, J.P.; Sapiano, M.; San-Sebastián, J.; et al. A risk assessment methodology to evaluate the risk failure of managed aquifer recharge in the Mediterranean Basin. Hydrol. Earth Syst. Sci. 2018, 22, 3213-3227. [CrossRef]

(C) 2020 by the authors. Licensee MDPI, Basel, Switzerland. This article is an open access article distributed under the terms and conditions of the Creative Commons Attribution (CC BY) license (http://creativecommons.org/licenses/by/4.0/). 